\title{
BIOCHAR STANDARDIZATION AND LEGISLATION HARMONIZATION
}

\author{
Sebastian MEYER ${ }^{\mathrm{a}}$, Lorenzo GENESIO ${ }^{\mathrm{b}}$, Ines VOGEL ${ }^{\mathrm{c}}$, Hans-Peter SCHMIDT ${ }^{\mathrm{d}}$, Gerhard SOJA ${ }^{\mathrm{e}}$; \\ Edward SOMEUS ${ }^{\mathrm{f}}$, Simon SHACKLEY ${ }^{\mathrm{g}}$, Frank G. A. VERHEIJEN ${ }^{\mathrm{h}}$, Bruno GLASER ${ }^{\mathrm{i}}$ \\ ${ }^{a}$ Wissenschaftliche Beratung Dr. Sebastian Meyer, Limesstraße 46b, 81243 München, Germany \\ ${ }^{b}$ Institute of Biometeorology, National Research Council, Via Giovanni Caproni 8 - I-50145 Firenze, Italy \\ 'Institute for Geographic Sciences, Department of Earth Sciences, Freie Universität Berlin, \\ Malteserstraße 74-100, G 100, 12249 Berlin, Germany \\ ${ }^{d}$ Ithaka Institute for Carbon Strategies, Ancienne Eglise 9, CH-1974 Arbaz, Switzerland \\ ${ }^{e}$ Austrian Institute of Technology GmbH, UFT, Konrad-Lorenz-Straße 24, 3430 Tulln, Austria

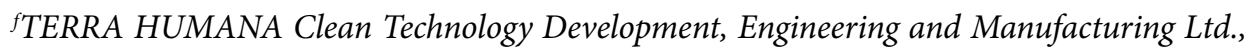 \\ H-2472 Kajaszo, Biofarm, Hungary \\ ${ }^{g}$ University of Edinburgh, School of Geosciences, Drummond Library, Surgeon's Square, \\ Drummond Street, Edinburgh EH8 9XP, United Kingdom \\ ${ }^{h}$ Centre for Environmental and Marine Studies (CESAM), Department of Environment and Planning, \\ Campus Universitário de Santiago, 3810-193 Aveiro, Portugal \\ ${ }^{i}$ Martin-Luther-Universität Halle-Wittenberg, Institut für Agrar- und Ernährungswissenschaften, \\ Bodenbiogeochemie, von-Seckendorff-Platz 3, 06120 Halle, Germany
}

Submitted 03 Jun. 2016; accepted 26 Oct. 2016

\begin{abstract}
It is a relatively new concept to use biochar as soil amendment and for climate change mitigation. For this reason, the national and supranational legislation in the $\mathrm{EU}$ is not yet adequately prepared to regulate both the production and the application of biochar. Driven by this "regulatory gap", voluntary biochar quality standards have been formed in Europe with the European Biochar Certificate, in the UK with the Biochar Quality Mandate and in the USA with the IBI Standard which is intended to be used internationally. In parallel to this, biochar producers and biochar users in a number of EU countries were partly successful in fitting the new biochar product into the existing national legislation for fertilisers, soil improvers and composts. The intended revision of the EC Regulation 2003/2003 on fertilisers offers the opportunity to regulate the use of biochar at the EU level. This publication summarizes the efforts on biochar standardization which have been carried out by voluntary products standards and illustrates existing legislation in EU member states, which apply to the production and use of biochar. It describes existing and planned EU regulations, which impact biochar applications and it develops recommendations on the harmonization of biochar legislation in the EU.
\end{abstract}

Keywords: biochar, criteria, European Union, EU Fertiliser legislation, harmonization, quality, regulation, standard, threshold.

\section{Introduction}

With the adoption of the Paris Agreement on the $21^{\text {st }} \mathrm{UN}$ FCCC Conference of the Parties in December 2015, the climate negotiators of 195 countries have unanimously agreed to hold the global average temperature well below $2{ }^{\circ} \mathrm{C}$ above preindustrial levels and to pursue efforts to limit the temperature increase to $1.5^{\circ} \mathrm{C}$ above preindustrial levels (United Nations Framework Convention on Climate Change 2015).

Smith et al. (2015) point out that the majority of the climate scenarios included in the Fifth Assessment Report of the Intergovernmental Panel on Climate Change with a

Corresponding author: Sebastian Meyer

E-mail: sebastian.meyer@wisber.eu 
$>66 \%$ probability of limiting global warming below $2{ }^{\circ} \mathrm{C}$ deploy large scale negative emission technologies (NETs). While these scenarios do not yet include biochar systems and other soil carbon sequestration strategies with NETs, Smith (2016) recommends including these options in future climate scenarios following his assessment of the sequestration potential, sequestration costs, and resource demands of these new options.

According to the reports "State of the Biochar Industry 2013 (and 2014)" released by the International Biochar Initiative, the volume of biochar sold globally strongly increased from 827 tonnes in 2013 to 7457 tonnes in 2014 . An average end consumer retail price of 3.08 US\$ per $\mathrm{kg}$ of biochar is indicated in the report for the year 2014, which would translate into a global biochar market volume of approximately 23 million US\$ at this point in time (International Biochar Initiative 2014, 2015b). Although the cited retail prices are very high (for comparison: wholesale retail prices for biochar of around $0.6 €$ per $\mathrm{kg}$ of biochar are common in the European Union in the year 2016), a future growth of the global biochar market may be predicted if the factors cited above are taken into account.

Since the concept of using carbonized biomass in the agricultural sectors for soil improvement and climate change mitigation (i.e. biochar) is relatively new, the national and supranational legislation in the European Union is not yet adequately prepared to regulate both the production and the application of biochar. This assessment can be best illustrated by the simple fact that the word "biochar" is not mentioned by name in any European or national legislation so far (Schmidt, Shackley 2016).

At least partly driven by this "regulatory gap", voluntary biochar quality standards have been formed in Europe with the European Biochar Certificate (EBC) (European Biochar Foundation 2012), in the United Kingdom with the Biochar Quality Mandate (BQM) (British Biochar Foundation 2014) and in the United States with the International Biochar Initiative Biochar Standards (IBI-BS) (International Biochar Initiative 2015a).

In parallel to this, biochar producers and biochar users in a number of EU countries were partly successful in

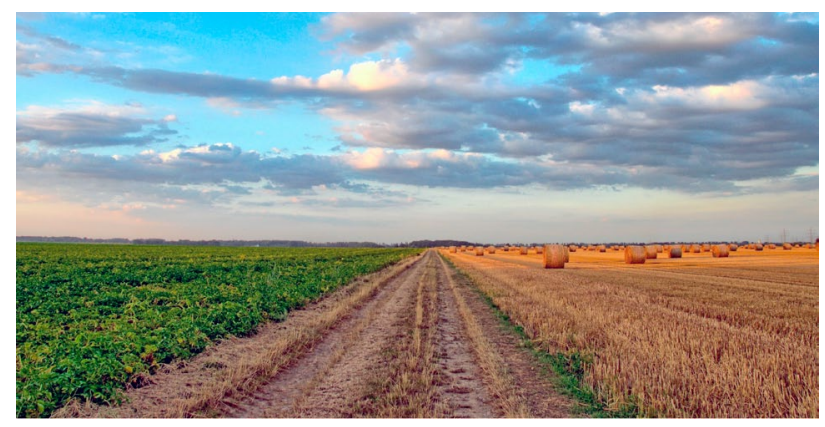

Fig. 1. The bumpy path towards biochar standardization and legalization harmonization in the European Union fitting the new biochar product into the existing national legislation for fertilisers, soil improvers and composts (see Fig. 1). In some cases, existing laws regulating the production and use of traditional wood charcoal offered a point of contact to integrate biochar in the existing legislative context.

The intended revision of the EC Regulation 2003/2003 on fertilisers (European Commission 2016) offers the opportunity to regulate the use of biochar at the European Union level (European Sustainable Phosphorus Platform 2015). This new piece of legislation might be influenced by the content of the existing EC Regulation No 66/2010 on the EU Ecolabel as well as of the EC Regulation No 1907/2006 concerning the Registration, Evaluation, Authorisation and Restriction of Chemicals (REACH).

This publication aims at:

- summarizing the efforts on biochar standardization and quality assurance which have been carried out by voluntary biochar products standards (see subchapter 1 )

- illustrating existing legislation in EU member states which applies to the production and use of biochar (see subchapter 2)

- describing existing and planned EU regulations which might apply to the production and use of biochar (see subchapter 3)

- deriving recommendations on the harmonization of biochar legislation in the European Union (see subchapter 4 and the section of conclusion and recommendations).

The paper is mainly based on the available documentation (until end of March 2016) about voluntary product standards, on legislative texts as well as on consultation papers on emerging legislation.

\section{Voluntary biochar product standards}

Voluntary product standards are already well known from a variety of products (e.g. the forest product standard Forest Stewardship Council - FSC or the palm oil product standard Round Table for Sustainable Palm Oil - RSPO). They aim to guarantee the sustainability and/or the quality of a product, thus enabling the consumers to better differentiate between products by voluntarily using these standards.

The development of the sustainability policy around biofuels in the European Union in the last decade has however shown that voluntary product standards can be integrated into upcoming legislation with the aim to guarantee the sustainability of e.g. biofuel production (Dehue et al. 2007). In this case, the voluntary standards are benchmarked against an overarching meta-standard written down in the respective legislation (e.g. the Renewable 
Energy Directive (2009/28/EC) (Official Journal of the European Union 2009). Voluntary standards that meet the minimum requirements of the overarching legislation can then be used to give a simple and cost-effective proof for the lawfulness of a product. This means that it is obligatory to meet the requirements of the meta-standard, and voluntary standards can be used as a proof that the obligation has been meet. This approach has the advantage of building upon existing standards without having to reinvent the wheel (Meyer et al. 2010).

For this reason, this chapter introduces the major characteristics of the existing voluntary biochar product standards. A detailed comparison of the technical thresholds of these standards will be presented later in chapter 4 .

\subsection{The Biochar Standard of the International Biochar Initiative (IBI-BS)}

The International Biochar Initiative is a non-profit association based in the Unites States, which has the aim of promoting good industry practices, stakeholder collaboration, and environmental and ethical standards to foster economically viable biochar systems. In 2015, it has published the version 2.1 of the "standardized product definition and product testing guidelines for biochar that is used in soil", i.e. the IBI-BS. The following summary of the standard design is based on International Biochar Initiative (2015a), Schmidt and Shackley (2016), and Lehmann and Joseph (2015):

The standard requires biochar products to have an organic carbon content of at least $10 \%$ and to have a hydrogen-to-organic carbon ratio (which is inter alia an indicator for biochar stability) of less than 0.7. The following product properties have to be declared: moisture content, total ash content, total nitrogen content, $\mathrm{pH}$-value, electrical conductivity (as a measure for the salinity of the product), $\mathrm{CaCO}_{3}$ content and particle size distribution.

The standard requires thresholds for heavy metals and organic pollutants including polycyclic aromatic hydrocarbons (PAH); polychlorinated biphenyls (PCBs); polychlorinated dibenzodioxins (PCDDs) and polychlorinated dibenzofurans (PCDFs). In addition, a germination inhibition assay has to be passed by the tested biochar products. A detailed overview of the threshold values will be given in chapter 4 .

The IBI-BS defines both sampling and analysis procedures. The testing frequency for the product quality depends on the type of feedstock (unprocessed vs. processed) and the production process (high carbon ashes from biomass fuelled power production (i.e. mainly combustion processes) have to be analysed quarterly with respect to pollutants to account for the higher pollution risks connected with this process). The biochar producers must keep records of biochar feedstocks including chain of custody and test results.
The IBI Biochar Certification Program staff verifies the documentation provided by the manufacturer and the assigned laboratories. There is no requirement for onsite production control (to check the manufacturer statements) and verification by an independent, governmental accredited certification body.

With the exception of hazardous municipal solid waste, no feedstocks are excluded from biochar production. There are no requirements regarding the sustainability of the feedstock or of the conduct of the biochar production process itself. The standard does not demand a greenhouse gas (GHG) balance for the product.

According to the website of the IBI, there are currently (April 2016) two biochar producers certified according to the IBI-BS.

\subsection{The European Biochar Certificate (EBC)}

In 2011, when the European Biochar Certificate (EBC) was introduced, biochar was a class of material not yet foreseen in EU and member states national legal frameworks. Governmental administrations of EU countries needed, therefore, a sophisticated product definition in order to integrate biochar in existing legally-binding fertilizer and soil ordinances (where these existed). In many cases, it had to be shown through production and quality standardization that biochar is not a waste but a manufactured quality product. As both biochar properties and the environmental footprint of biochar production are very much dependent on the technical control of the production technology and the type of feedstocks, a transparent control system for its production and analysis was introduced.

The main intentions of the EBC were: 1) to introduce a control mechanism based on the latest research and practices; 2) to provide customers with a reliable quality basis, while; 3 ) to give producers the opportunity of proving that their product meets well-defined quality standards; 4) to provide a firm state-of-the-art knowledge transfer as a sound basis for future legislation; and 5) to prevent and hinder misuse or dangers right from the start.

Biochar producers' compliance with European Biochar Certificate requirements is coordinated throughout Europe by the independent, governmental accredited quality assurance agency q.inspecta, with inspections of production plants in individual countries carried out by independent national inspection agencies. On-site inspections take place once a year. In order to be reasonably proportional to the risk assessment and to the environmental protection goals, producers with an annual production capacity below $50 \mathrm{t}$ of biochar are exempt from on-site inspection of production. The compliance with production requirements is in the latter case controlled by the accredited quality assurance agency via self-declaration and a detailed description of the complete production process. 
The requirements for biochar batch analyses, thresholds, feedstock sustainability and handling of biochar maintain the same as for industrial producers.

Accredited laboratories for biochar analysis have to apply the EBC analytical methods for all measurements and have to prove their compliance in regular ring trials or interlaboratory comparisons (Bachmann et al. 2016). The main analytical variables are the elements $\mathrm{C}, \mathrm{H}, \mathrm{N}, \mathrm{O}$, and $\mathrm{S}$, ash, main elements, heavy metals, organic contaminants (PAH, PCB, PCDDs and PCDFs), $\mathrm{pH}, \mathrm{EC}$, and specific surface area as described in (Bachmann et al. 2016) and (European Biochar Foundation 2012).

In accordance with the certificate to which the EBC guidelines apply, a differentiation is made between two different biochar grades, each with its own threshold values and ecological requirements: "basic" and "premium". A detailed overview of the threshold values will be given in chapter 4 . The main differences between both grades are the thresholds for heavy metals, organic pollutants and feedstock requirements. While the thresholds of the basic quality grade are based on Germanys Federal Soil Protection Act (Bundes-Bodenschutzverordnung), the thresholds for premium quality grade follows the more severe Swiss Chemical Risk Reduction Act (Der Schweizerische Bundesrat 2005).

The EBC lists and defines all types of biomass feedstocks that are allowed to be used for biochar production in the feedstock positive list. Moreover, a number of sustainability aspects of the production process including emissions, energy efficiency, heat recovery, feedstock procurement (e.g. the feedstock should in general not transported more than $80 \mathrm{~km}$ to the pyrolysis plant), biochar storage, fire and dust protection, handling, and labelling are controlled.

By the end of 2015, twelve industrial producers from Germany, Austria, Switzerland, Italy, and Belgium were EBC certified.

\subsection{The British Biochar Quality Mandate (BQM)}

The BQM is a UK-specific initiative that was initiated in 2011 with the generous support of the Esmée Fairbairn Foundation. The BQM was authorised at a meeting of the British Biochar Foundation (BBF) in 2013 and version 1 released in July 2014. The BQM is managed by the BBF but was created through cooperation between scientists, policy makers and regulators in the UK, a process that included two panel meetings.

The BQM follows an approach taken in the UK of creating official guidance documents for specifying those conditions under which a waste-derived material can be regarded as a non-waste (achieving "end of waste" status). 14 such guidance documents called Quality Protocols have been created, including for compost, poultry litter ash, anaerobic digestate and biodiesel. The BQM is entirely voluntary and, while government input was obtained during its formulation, it does not have government endorsement in the way that a Quality Protocol does. The $\mathrm{BQM}$ also applies to biochar produced from material that is not initially designated as waste. The BQM follows the IBI and EBC in specifying Maximum Permissible Limits (MPLs) for toxicants (see also chapter 4), in addition to identifying key properties of biochar such as water holding capacity, porosity, bulk density, cation exchange capacity, specific surface area, labile and long-term stable carbon, available $\mathrm{P}$ and $\mathrm{N}$, release dynamics of $\mathrm{P}, \mathrm{K}$ and $\mathrm{N}$, impact on soil aggregation, priming potential, and so on. The formal definition of biochar adopted in the BQM is that the biochar must contain $\geq 10 \%$ organic carbon, a more flexible threshold than the EBC, but consistent with the low end of IBI's guidance. Similarly to EBC, the BQM has two quality grades of biochar, standard grade and high grade, the difference between them being more demanding MPLs for high grade biochar with respect to heavy metals. There is no difference between the two grades in limits for persistent organic pollutants, namely PAHs, PCDDs, PCDFs and PCBs. The BQM draws upon the IBI and other proposed limits where ever possible.

The evaluation of the sustainability of feedstocks is an important feature of the BQM. The three components of this are (i) monitoring the source of the biomass (including chain of custody), (ii) evidence that the biomass source was legally and sustainably managed, and (iii) use of Life Cycle Assessment (LCA) methodology to ensure a minimum greenhouse gas saving is met compared to alternative uses of the biomass. Users of small quantities of biomass (below 4 tonnes per day of feedstock) are exempt from sustainability reporting as are those using domestic waste feedstocks (with the exception of chain of custody reporting), though users of imported waste feedstocks ( $\geq 4$ tonnes per day) are not exempt. The BQM adopts six principles to ensure legal and sustainable sourcing of biomass, drawn from the EU's Renewable Energy Directive (RED) and UK government guidance on timber procurement. The LCA method adopted follows the RED though recommends inclusion of indirect land-use change factors where appropriate. The BQM proposes that the maximum net life-cycle GHG emissions per unit of feedstock consumed has to be lower than the respective life-cycle GHG emissions per unit feedstock were that biomass to be combusted instead in a modern bioenergy facility. It is not possible to provide a single value of net GHG emissions per unit feedstock that should not be exceeded due to differences in the calorific value of feedstocks and in the carbon stability of biochar carbon.

As for production, the BQM draws upon existing UK and EU legislation and associated guidance (Clean Air Act 1993, Renewable Heat Incentive) but supplemented 
with emission performance standards from the Commonwealth of Massachusetts 2010, which were developed specifically for biochar production. These standards refer to particulate matter, Volatile Organic Compounds (VOCs) and carbon monoxide (CO).

The BQM covers application of biochar, such that use is safe and responsible so as to avoid harm to humans or ecosystems. The Potential Toxicant Limiting Application Rate (PTLAR) is adopted, defined as the rate at which standard grade biochar can be applied without exceeding MPLs of potential toxicants in soil. Clearly, a threshold on toxicant per $\mathrm{kg}$ of biochar does not guarantee environmental safety without reference to total amount added per unit (area $\times$ depth) per unit time and it is this further safeguard that the PTLAR method endeavours to capture.

The MPLs for heavy metals are borrowed from the Code of Practice for Agricultural use of Sewage Sludge, supplemented with soil guideline values for persistent organic pollutants provided by the Environment Agency (England). In order to protect soil ecology and biodiversity, it is proposed that biochar is not applied in designated nature conservation areas such as Special Areas of Conservation, Special Protection Areas, etc. Keeping within limits of nitrogen addition in Nitrate Vulnerable Zones also needs to be monitored.

Due to the lack of commercial activity in the biochar sector in the UK in the past 4 years, no product has been accredited through the BQM as yet, though two such products are in the assessment pipeline. The BBF intends to update the BQM during 2016/2017 to include new developments at the EU level and to extend to novel applications of biochar.

\section{National legislation related to biochar manufacturing, product quality and applications}

The following subchapters summarize the main aspects of the legal situation concerning the production and application of biochars in Germany, Austria, Switzerland and Italy. A helpful, complementary overview on biochar legislation in Belgium (Flanders), Denmark, the Netherlands, Norway and the United Kingdom is given by Jim Hammond et al. in (Schmidt, Shackley 2016). Figure 2 depicts the analyzed countries as described above.

\subsection{Biochar legislation in Germany}

According to attachment 2, chart 7, subitem 7.1.10 of the German Fertilizer Ordinance (Bundesministerium der Justiz und für Verbraucherschutz 2012a) only charcoal produced from chemically untreated wood is listed as an input material for growing culture media as well as a carrier substance for the addition of nutrients via registered fertilizers. Moreover, such charcoal should have a carbon content $>80 \%$.
Other suitable input material for the production of biochar like waste material from foodstuff, drinks and tobacco industries, agriculture, forestry, horticulture and landscaping are allowed to be used as input media for growing culture media in its original form as well as its ashes (see attachment 2, chart 7, subitem 7.1 of the German Fertilizer Ordinance). Also the German Biowaste Ordinance (Bundesministerium der Justiz und für Verbraucherschutz 2013) allows the soil application of ashes from the burning of any kind of plant material, animal bones, sewage sludge or paper (see Attachment 1 of the German Biowaste ordinance).

The German Fertilizer Ordinance does not give any limitation regarding the rate of charcoal application per unit area or unit mass of soil. Only the German Biowaste Ordinance limits indirectly the application of biochar regarding co-composting with compost as the total compost application is limited up to 20 or $30 \mathrm{t}$ dry matter/hectare within a period of 3 years.

If biochar is applied together with slurry there is no limit concerning material amount though the total nitrogen load of the mixture will be a constraint: the German Fertilizer Application Ordinance (Bundesministerium der Justiz und für Verbraucherschutz 2012b) specifies that $\mathrm{N}$ additions should not exceed $170 \mathrm{~kg}$ total $\mathrm{N} \mathrm{ha}{ }^{1} \mathrm{a}^{-1}$ on arable land or $230 \mathrm{~kg}$ total $\mathrm{N} \mathrm{ha}{ }^{1} \mathrm{a}^{-1}$ on grassland.

The German Fertilizer Ordinance regulates thresholds for certain mineral and organic pollutants for all

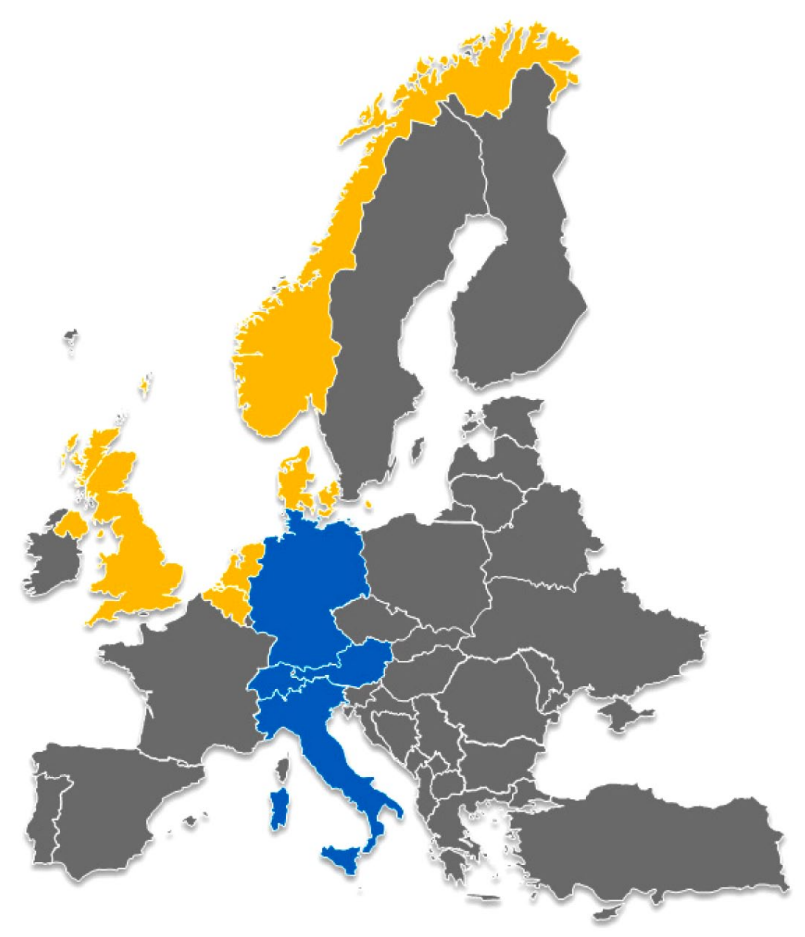

Fig. 2. Review of national biochar legislation in Schmidt and Shackley (2016) (analyzed countries are depicted in yellow color) and in this article (analyzed countries are depicted in blue color) 
fertilizers with the exception of manure fertilizer; this concerns arsenic, lead, cadmium, chromium, nickel, mercury, thallium, dioxin, dl-polychlorinated biphenyls and perfluorated tensides (see also chapter 4). The Copper and Zinc contents of fertilizers have to be reported. In principle, these requirements should also apply to biochar and most are in accordance with requirements of the European Biochar Certificate.

However, there is no threshold in the German Fertilizer Ordinance for polycyclic aromatic hydrocarbons that are often generated in carbonization processes.

The German Federal Soil Protection and Contaminated Sites Ordinance (Bundesministerium der Justiz und für Verbraucherschutz 1999) gives precautionary values for soil with low $(<=8 \%)$ and high humus content $(>8 \%)$ regarding the total content of 16 priority $\mathrm{PAH}$ as defined by the Environmental Protection Agency of the United States (EPA $16 \mathrm{PAH}$ ), namely $3 \mathrm{mg} / \mathrm{kg}$ soil and $10 \mathrm{mg} / \mathrm{kg}$, respectively. Biochar is intended to rest in soil for long periods so it seems prudent to apply comparable quality parameters also as thresholds for biochar soil application.

A quality control of new char materials is discussed to be given by the association of producers who carbonize different feedstocks (composts, digestates, sewage sludge, ashes). On the basis of the existent legislation this kind of self-control may contribute to establish high-grade soil improvers (Haubold-Rosar et al. 2016).

\subsection{Biochar legislation in Austria}

In Austria, it is currently not permitted to use biochar as primary material for fertilizers, soil amendments or growth substrates because it does not fulfill the requirements of one of the fertilizer types listed in the Austrian Fertilizer Ordinance (Bundeskanzleramt Österreich 2004). Therefore, the marketing of biochar as a component of a fertilizer product according to DMVO 2004 is not possible. However, there is the possibility under the Austrian Fertilizer Law of achieving an individual permission to use a fertilizer containing biochar on the basis of a special notification by the authorities (DMG) 1994, \$9a (Bundeskanzleramt Österreich 1994), in the case that a product does not comply with the type descriptions in DMVO 2004. The responsible authority is the Federal Office for Food Safety. The allowance is issued with a special notification upon request of the producer after an extensive assessment procedure if the subsequent conditions are met: a benefit of the product must be proven (e.g. fertilizer effect, or a positive influence on physical or chemical soil characteristics), the nutrient concentration must be known and appropriately declared, the threshold concentrations of contaminants must not be exceeded (see chapter 4 ). If the product complies with the defined requirements, the authorities have to issue a permission which can be linked to certain obligations, e.g. the required frequency of analyses for defined quality parameters. Such permission is only given for a limited period of time and has to be renewed after then.

Currently, the use of biochar as an additive for composting is not allowed under the Austrian Composting Ordinance. If biochar were to be added to compost, this compost would become waste because the other compost input materials cannot then satisfy the end of waste requirements. So the compost would have to be sold as waste. In 2016 the Composting Ordinance will be revised and it is expected that these regulations might change. In preparation of such changes a new Austrian Standard (ÖNORM S 2211-1) is being developed that regulates the quality criteria for biochar. If a certain biochar would comply with this future standard, an addition of this biochar to compost might be considered as acceptable without violating the end of waste criteria.

\subsection{Biochar legislation in Switzerland}

In April 2013, Switzerland was the first country in Europe to officially approve the use of certified biochar in agriculture. Following an exceptionally thorough 3-year approval procedure involving the various research groups of the Biochar Science Network of Switzerland and the Federal Ministries of the Environment and of Health, the Swiss Federal Ministry of Agriculture issued a conditional approval for the use of biochar in agriculture (Schweizerische Eidgenossenschaft 2013). The approval is based on strict, scientifically checked requirements with regards to the sustainability of biochar production, biochar quality and user protection in its application (see also chapter 4). All biochar certified as EBC premium quality (European Biochar Foundation 2012) can, since spring 2013, be used as a soil amendment in agriculture as long as the feedstock used for the production of the EBC-certified biochar consists of woody materials (Schweizerische Eidgenossenschaft 2013). In 2016, a renewal of the approval is expected including this time more types of feedstock. Since 2016, biochar certified as EBC feed grade biochar can be sold as organic animal feed (e.g. to absorb toxic fodder compounds).

\subsection{Biochar legislation in Italy}

On 12 August 2015, the edition No. 186 of the Italian law gazette "Gazzetta Ufficiale Della Republica Italiana" published a modification of the Annexes 2 and 7 of the fertilizer decree number 75 of 29 April 2010 (Decreto Legislativo... 2010). With these modifications, made following a request presented by the Italian Biochar Association (ICHAR), the Italian Ministry of Agriculture, Food and Forestry included biochar in the list of soil amendments which are permitted to be used in the Italian agricultural sector and defined technical specifications for this product. 
The technical specifications require biochar to be produced exclusively from traceable biomass of vegetal origin from the agro-forestry sector, to have an organic carbon content of at least $20 \%$ and to have a hydrogento-organic carbon ratio of equal or less than 0.7 . The total ash content may not exceed $60 \%$; the $\mathrm{pH}$-value shall be between 4 and 12 and the electrical conductivity below $1.000 \mathrm{mS} / \mathrm{m}$. The moisture content of powdery biochar products should exceed $20 \%$.

The following product properties have to be declared: particle size distribution, total nitrogen content, total potassium content, total phosphorus content, total calcium content, total magnesium content and the total sodium content. The percentage of carbon from carbonates in the product as well as its maximum water retention has to be indicated. In addition to that, the results of a germination inhibition assay and a worm avoidance test have to be reported.

The revised version of Annex 2 includes thresholds for heavy metals and defines three biochar quality classes based on $\mathrm{C}$ and ash content. Thresholds for organic pollutants (PAH, PCDDs, PCDFs and PCBs) have been set by the decree of 28.06.2016 in GU Serie Generale n.188 (see Ministero delle politiche... 2016). A detailed overview of all threshold values will be given in chapter 4 . The modification of Annex 7 defines measurement tolerances for the requested analyses. A further modification of the Annex 13 for the inclusion of biochar in the list of amendments allowed in organic agriculture has been requested by ICHAR and is currently under the evaluation of the Ministry of Agriculture, Food and Forestry.

\section{EU level legislation related to biochar manufacturing, product quality and applications}

As already mentioned above, the word "biochar" does not yet appear in the current legislation of the European Union at all. Nonetheless, there are several points of contacts with the existing legislation of the EU such as the EC regulation 66/2010 on the EU Ecolabel (Official Journal of the European Union 2010) and the EC regulation 1907/2006 concerning the Registration, Evaluation, Authorisation and Restriction of Chemicals (REACH) (Official Journal of the European Union 2007).

Besides that, the revision of the EC regulation 2003/2003 (Official Journal of the European Union 2003) on fertilisers is currently in progress. The objectives of this revision are to make the new fertiliser regulation more flexible, in order to be able to authorise new products (in particular recovered and recycled products, including organic materials) as Conformité Européenne (CE)-labelled fertilisers. The new regulation is planned to be complemented by annexes setting out specifications for different products. The European Commission (EC) has indicated the intention to start with product annexes for composts and digestates, struvite, biomass ashes, and biochars when the revised fertiliser regulation is adopted (European Sustainable Phosphorus Platform 2015).

The following subchapters give an overview of the relevant existing legislation and intended legislation revisions.

\subsection{Results from the FP7 research project REFERTIL}

REFERTIL was an EU co-funded applied research project, biochar production industrial engineering, product development, application and EU policy support project for the "Improvement of comprehensive bio-waste transformation and nutrient recovery treatment processes for production of combined natural products" within the $7^{\text {th }} \mathrm{EU}$ Framework Programme for Research and Technological Development which has been carried out between 2011 and 2015 as upgrade of the project partners extensive biochar development activities since 2002 under EU Framework Programmes (Terra Humana Ltd 2014).

The REFERTIL project aimed at establishing a regulatory framework to enable the production and use of biochar soil improvers, growing media and/or fertilizers under market competitive conditions while removing barriers to trade and use biochar products on the internal market of the European Union. The aim of the project was to ensure that the proposed biochar quality and safety criteria are fully consistent with existing EU Directives and Regulations with consideration of Member States legal frameworks. The key objective of REFERTIL was to improve the resource efficiency by developing an advanced biochar-processing technology and to develop products in line with the circular economy models. The project also aimed at developing innovative fertilizers, as well as recovering and recycling nutrients and organic matter from bio-waste or secondary raw materials.

There is no one fit for all biochar production process and/or product type. Biochars with a high carbon content can serve (under certain conditions) as soil improver and/ or growing media. Plant-derived biochar generally has a very low direct fertilizer value, but it often has a high water holding and nutrient retention capacity besides a high $\mathrm{C}$ sequestration potential. Biogenic chars produced from food grade animal bones have far lower carbon content and a high $\mathrm{P}_{2} \mathrm{O}_{5}$ content which increases the fertilizers value of these chars substantially. For this reason, REFERTIL proposed quality standards both for animal bone derived biochars as innovative Phosphorus fertilizer and plant-derived biochars. PAH priority hazardous substances are biochar key performance indicators both for the production process and product quality as well. The Potential Toxic Elements (PTE) and the organic pollutant threshold values for plant and food grade animal bone 
derived biochars recommended by the REFERTIL project are outlined in detail in chapter 4 .

Biochar production and application in agriculture has to be mandatorily permitted according to the EU/ MS regulations. The first biochar application permit of an EU Member State has been issued in 2009 for Terra Humana Ltd (permit number 02.516717120). Member States legislations are based on complex EU regulations and therefore, this permit is directly interlinked to several EU regulations, while Mutual Recognition of Member State permit in another Member States is to be applied under EU regulation.

In this context, the key driver is the application purpose, such as soil improver, growing media, organic fertilizer or microbiological substance, if the product fits in and meets relevant criteria according to the EU/MS legislation. There are valid and mandatory regulations already existing in the Member States for such product quality and permit scenarios according to EU system, but not yet EU28 law harmonized. The EC2003/2003 Fertilizer Regulation revision aiming the full EU28 law harmonization, same as for mineral fertilizers as EC fertilizers, under which biochar may also be included.

The development of the specific pyrolysis process original solution by Terra Humana Ltd has been extensively co-financed by the EU since 2002 to progress from biochar science towards industrial applications, e.g. to progress from low Technology Readiness Level (TRL) research maturity to advanced high TRL. The ultimate REFERTIL goal is TRL9 biochar: competitive manufacturing of plant and animal bone-based products from small industrial installations with $6500 \mathrm{t} / \mathrm{y}$ throughput to economically medium scale $20800 \mathrm{t} / \mathrm{y}$ scenarios.

The permit for Terra Humana has been "CLP"-upgraded in 2015. The CLP Classification, Labelling and Packaging Regulation under ECHA ensure that the hazards presented by chemicals are clearly communicated to workers and consumers in the European Union through classification and labelling of chemicals.

\subsection{EU requirements under REACH}

It is currently being debated whether a REACH registration is mandatory for biochar products or not. To set up a REACH dossier, it is mandatory to use Good Laboratory Practice and accredited laboratory results. The REFERTIL project participants find the REACH registration fully justified for the biochar case and puts high responsibility on the producer and user with regard to a product that is irrevocably applied in soil. Due to the substantial costs associated with REACH registration, a REACH registration requirement might constitute a very high market entry barrier for small biochar producers (van Laer et al. 2015). Although REACH certification costs are high, lower production volumes require fewer REACH evaluations (translating into lower costs). Cost sharing by a joint biochar stakeholder application is also a viable opportunity.

Waste material streams are not covered by REACH, but are rather covered by the Waste Framework Directive 2008/98/EC (Official Journal of the European Union 2008) and other waste material related directives. Waste products are regulated by End-of-waste (EoW) criteria which specify when certain wastes cease to be waste and obtain the status of a product (or a secondary raw material). After having agreed a methodology with the Member States, the Commission is now preparing a set of end-of-waste criteria for priority waste streams. If a waste-derived (alternative feedstock) carbon product successfully reaches the EoW status, e.g. it is converted from a waste material to a biochar product with relevant quality and safety, than the new biochar product might have to be registered under the REACH directive. The EU/MS law harmonisation is still under progress for waste-derived carbon products and is estimated to be possibly completed before 2020 together with the finalisation of the EC2003/2003 Fertilizer Regulation revision.

\subsection{Biochar characterization criteria proposed by the European Sustainable Phosphorus Platform for the Revision of the EC Regulation 2003/2003 on fertilizers}

The European Sustainable Phosphorus Platform (ESPP) is a non-profit organisation registered in Belgium with the objective to contribute to phosphorus sustainability in $\mathrm{Eu}-$ rope. ESPP has proposed to the EC to prepare draft product criteria to be used for the intended annex on biochar products to the revision of the EC regulation 2003/2003.

These draft product criteria shall be used as input to the Joint Research Centre (JRC) of the European Union. The JRC will carry out a formal consultation on this topic and shall draft all product annexes (for biochars, composts and digestates, struvite, and biomass ashes as already mentioned above) to the revision of the fertiliser regulation (European Sustainable Phosphorus Platform 2015).

In the following, the content of the version v17/3/2016 of the draft biochar characterization criteria proposed by the European Sustainable Phosphorus Platform is described (see also European Sustainable Phosphorus Platform 2016):

The draft annex is intended to define criteria for the validation of biochars to be used as fertilisers, soil amendments or growing media. It uses the following biochar definition:

"Biochar is produced from various types of biomass, under controlled pyrolysis or gasification: a thermal process whereby organic substances are transformed (partly decomposed) in low-oxygen (reductive) conditions".

The document further clarifies that products from torrefaction, hydrothermal carbonization and coke 
production shall not qualify as fertilisers under the revised fertiliser regulation (EUFR biochars).

The draft annex proposes to categorise a non-exclusive selection of potential biochar feedstock materials to be able to differentiate between required process parameters and testing requirements. Currently, the following material categories are foreseen:

1. Animal by-products;

2. Animal manures and slurries;

3. Municipal sewage biosolids;

4. Plants, plant parts, including after non-chemical processing and including after extraction or purification processes;

5. Organic-based used growing media, such as mushroom soil or peat;

6. Food and beverage industry waste;

7. Bio-waste within the meaning of Directive 2008/98/EC resulting from separate bio-waste collection at source, including collectivity kitchen and canteen food wastes;

8. Mechanically separated organic fraction of municipal wastes;

9. Industry biomass wastes or biomass by-products susceptible to contain $<1 \%$ synthetic chemicals;

10. Any material which is conform to EUFR Component Material Category criteria;

11. Any material generated by mechanical processing, heat processing, washing, drying, extraction or refining, composting, anaerobic digestion or pyrolysis of the above materials or of mixtures of these.

The draft annex explicitly excludes biochars from hazardous chemical wastes, hospital wastes, radioactive materials and (mixed) municipal solid waste (waste streams with more than 5\% mixed, unsorted or residual municipal solid refuse).

The following organic or inorganic additives, added before biochar processing or after processing (mixed into the biochar product) may be used if necessary to facilitate the process or ensure the final product agronomic or other characteristics:

- Process catalysts or additives;

- Minerals such as calcium, sulphur, lime;

- Polymers or cohesives to prevent dusting.

The maximum total of such additives is $1 \%$ in input material and $1 \%$ in product.

The draft annex envisages the following biochar product criteria:

Biochars shall have an organic carbon content of at least $30 \%$ and have a hydrogen-to-organic carbon ratio of less than or equal to 0.7 .

The moisture content of powdery biochar products ( $>10 \%$ of particles diameter $<100 \mu \mathrm{m}$ ) should be in the range of $30-40 \%$. As an alternative, the biochar product should be pelletized to avoid dusting at the application.
It is not suggested to set up specific heavy metal limits for biochar, but to require biochars to meet the limits of the revised fertiliser regulation for heavy metals (this might include limits for $\mathrm{Cd}, \mathrm{CrVI}, \mathrm{Hg}, \mathrm{Ni}, \mathrm{Pb}$, As and the requirement to report the $\mathrm{Cu}$ and $\mathrm{Zn}$ content of the biochars). A detailed overview of the threshold values (which are currently still under discussion) will be given in chapter 4.

For PCDDs and PCDFs, a combined threshold of $<20 \mathrm{ng} / \mathrm{kg}$ shall be set. The maximum content of PCBs may not exceed $0.2 \mathrm{mg} / \mathrm{kg}$.

It is proposed to apply the same PAH limit $(6 \mathrm{mg} / \mathrm{kg})$ as currently included in the draft fertiliser regulation revision for composts, organic fertilisers and organic soils improvers. It should be noted that several pyrolysis and gasification technology providers might not be able to meet this limit (for comparison, the EBC standard (see chapter 1.2) sets a maximum PAH limit of $12 \mathrm{mg} / \mathrm{kg}$ ).

Regarding biochar physio-chemical characterization, the biochar COST Action (TD1107) has pushed forward the necessity to integrate contaminant quantification with effect-based characterization approaches that reflect the potential risks of biochar to soil biology and functional diversity (Bachmann et al. 2016).

The draft annex allows to use the PAH analysis methods DIN ISO 13877:1995-06 Principle B (Soxhlet extraction with toluene) and DIN EN 15527:2008-09 (with the solvent toluene)). It should be noted that DIN EN 15527 allows for two extraction methods: ultrasonic-extraction/ shacking and (hot) Soxhlet extraction. Due to the lower extraction temperature and the lower amount of extraction cycles, there is a risk that substantially lower PAH values are identified in the biochars if the ultrasonic-extraction method/shacking is used.

Amongst others, the following product properties have to be declared: producer data, identity and location of production site, production site operating permit number or reference, EPR Extended Producer Responsibility certificate number or reference, production series number, bulk density, particle size distribution, $\mathrm{pH}$ value, water content, specific surface area, total nitrogen content, total potassium content, total (and the water soluble) phosphorus content, total calcium content, total magnesium content and total iron content. In addition to that, the salinity $(\mathrm{Na}, \mathrm{Cl})$ has to be indicated for biochars from certain feedstocks. Also, the product labelling shall specify whether the biochar has been produced from municipal sewage sludge, animal by-products or manure.

It is currently being debated (see also subchapter 3.2) whether a registration according to $\mathrm{REACH}$ will be necessary for biochar products.

There are no suggestions for control and monitoring criteria included in the draft annex yet. 


\section{Harmonization of biochar legislation in the European Union}

The presented standards and legislative regulations to standardize biochar products can be evaluated systematically to support the drafting of harmonized biochar legislation for the European Union.

In the following table (Table 1), the standardization approaches discussed already above are compared sideby-side. The comparison includes the suggested quality requirements for biochars, the respective threshold values for organic pollutants and heavy metals as well as additional requirements set by the approaches.

\section{Conclusions and recommendations}

This section summarizes the analysis of the reviewed standardization approaches and the reviewed legislation proposals. The advantages and disadvantages of different policy options are highlighted in this context.

Seen from a top-down perspective, the quality requirements for biochar, the organic pollutant thresholds and the heavy metal thresholds depicted in Table 1 in chapter 4 follow the same systematic approach, be it in voluntary certification systems, national legislation or suggested EU level legislation. It should be possible to derive sensible quality requirements and threshold values from the overview.

In this context, it should be noted that the hydrogen/ organic carbon ratio is a key indicator for many aspects: the process conditions (temperature and residence time) under which biochar has been produced, the risk for microbial contamination (since biochars with low $\mathrm{H} / \mathrm{C}$ ratio have been exposed to high temperatures and/or long heat residence times), and the biochar stability. All reviewed standards ask for a maximum hydrogen/organic carbon ratio of 0.7 .

While the $\mathrm{O} / \mathrm{C}$ ratio is also a good indicator for biochar stability (a maximum value of 0.4 is defined in the EBC standard), a low $\mathrm{O} / \mathrm{C}$ ratio requirement might exclude the production of activated biochars.

It should not be forgotten that $\mathrm{PAH}$ threshold values are only meaningful if they are seen in combination with the permitted PAH analysis methods. Hot PAH extraction methods using a Soxhlet apparatus and the solvent toluene (e.g. according to the analysis method DIN ISO 13877:1995-06 Principle B) will find substantially (sometimes in the order of magnitudes!) higher PAH contents in biochars as compared to other methods (Hilber et al. 2012; Meyer et al. 2014).

A recent study of (Genesio et al. 2016) illustrates that the negative (cooling) impact of biochar systems on the climate might be inverted if a considerable fraction of the produced biochar is released into the atmosphere in form of ultrafine black carbon aerosols $\leq 25 \mu \mathrm{m}$. Since these particles absorb shortwave radiation, they increase Radiative Forcing, thereby contributing to global warming. This underlines the necessity to moisten biochar products (which could be efficiently carried out directly after biochar production) to prevent black carbon aerosol formation if the climate mitigation benefit of biochar systems shall be maintained. Pelletizing and composting biochar are other methods to reduce the dust emissions of biochar soil incorporation.

The reviewed systems are characterized by more fundamental differences if the additional requirements on the bottom of Table 1 are taken into consideration.

Limiting the potential feedstocks used to produce biochar may help to avoid pollution risks which cannot be easily captured with the organic pollutant thresholds and heavy metal thresholds. However, these limitations inevitably limit the feedstock potential for biochar production. From an ecological point of view, the loss of nutrients (especially nitrogen) during pyrolysis and gasification should be avoided in case a composting of the same material with lower nutrient losses (e.g. via co-composting with biochar) is possible (although the GHG emissions of the composting process need also to be considered). This might be an argument to exclude certain nutrient rich feedstocks from biochar production. The question whether parts of dead animals should be used as feedstock for biochar production should also be answered from an ethical point of view.

Sustainability requirements for biochar feedstock production are integrated in the BQM and the EBC standard. The BQM offers sustainability standards in line with the with the EU Renewable Energy Directive and proposed revisions for solid biomass supply to be able to guarantee a positive GHG balance of biochar systems (besides additional ecological and social requirements). To avoid a competition between biochar production and food production, biochar production could be restricted to biogenic residues (excluding biochar production from dedicated biochar crops on land suitable for food production).

There is a tendency to focus on pyrolysis technologies for biochar production. Gasification is another option to produce stable biochars. Since gasification biochars bear a higher risk of organic pollution (Schimmelpfennig, Glaser 2012; Meyer et al. 2014), a strict enforcement of corresponding threshold values needs to be guaranteed. Whether or not required quality standards for biochar production are met in reality is strongly connected to the verification systems installed. On-site verification as implemented by the EBC standard clearly supports standard enforcement.

Verheijen et al. (2012) first suggested the concept of "integrating biochar properties with environmental 


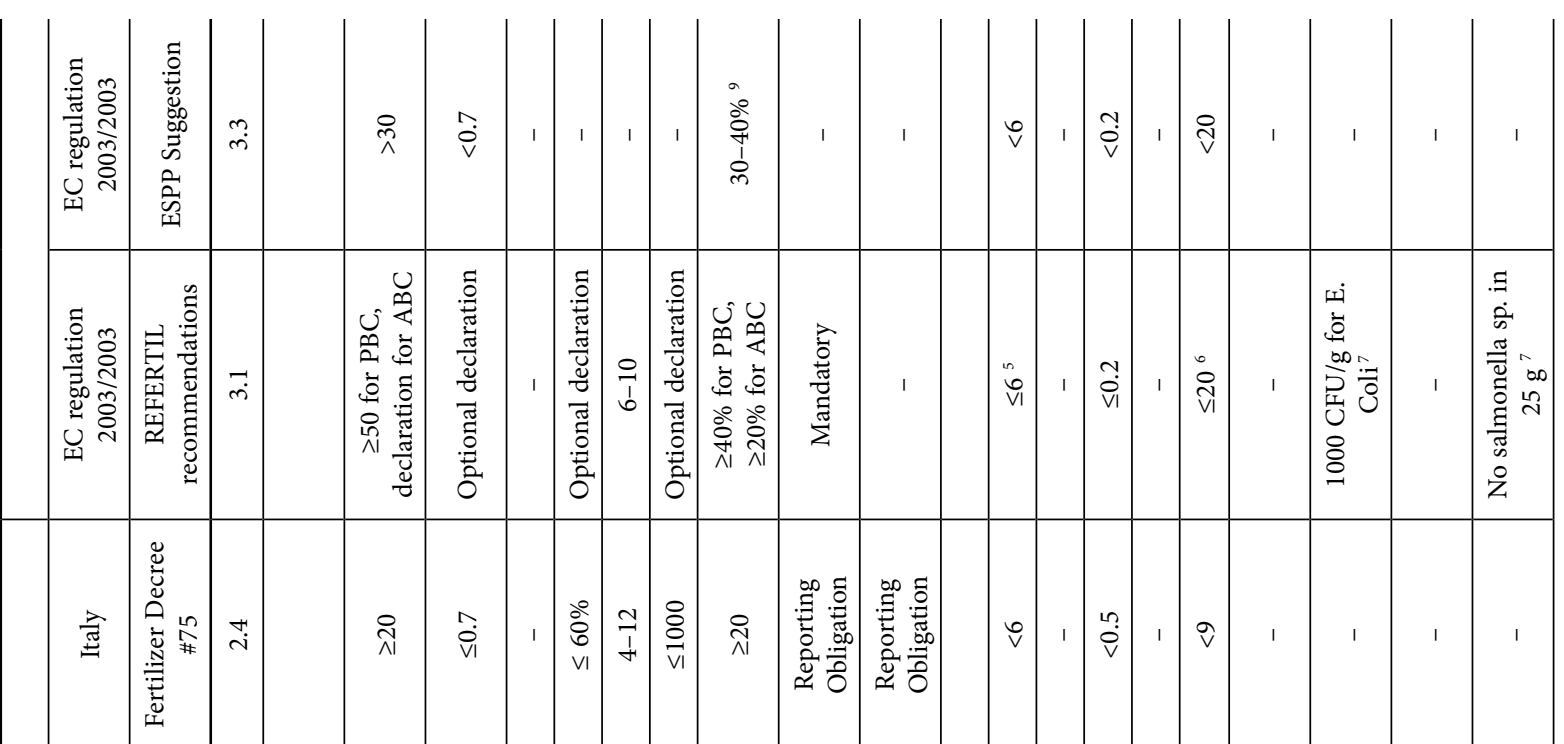

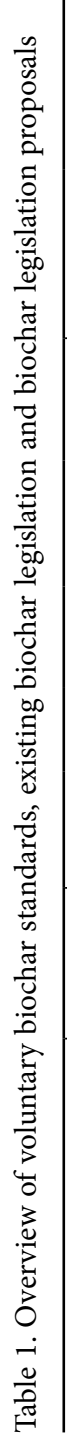

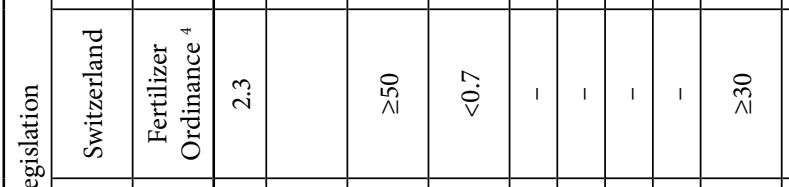

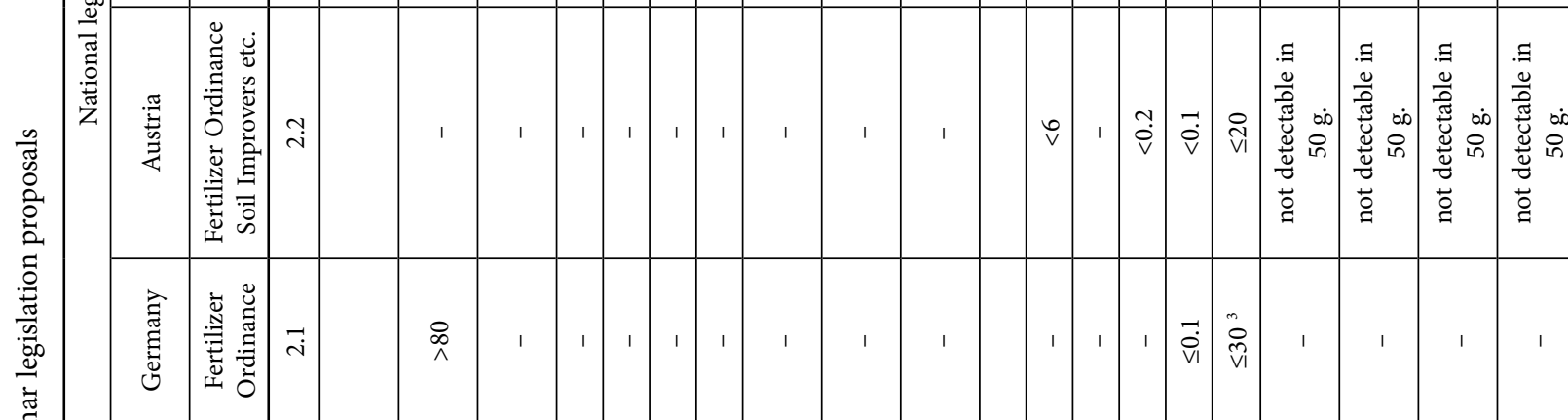

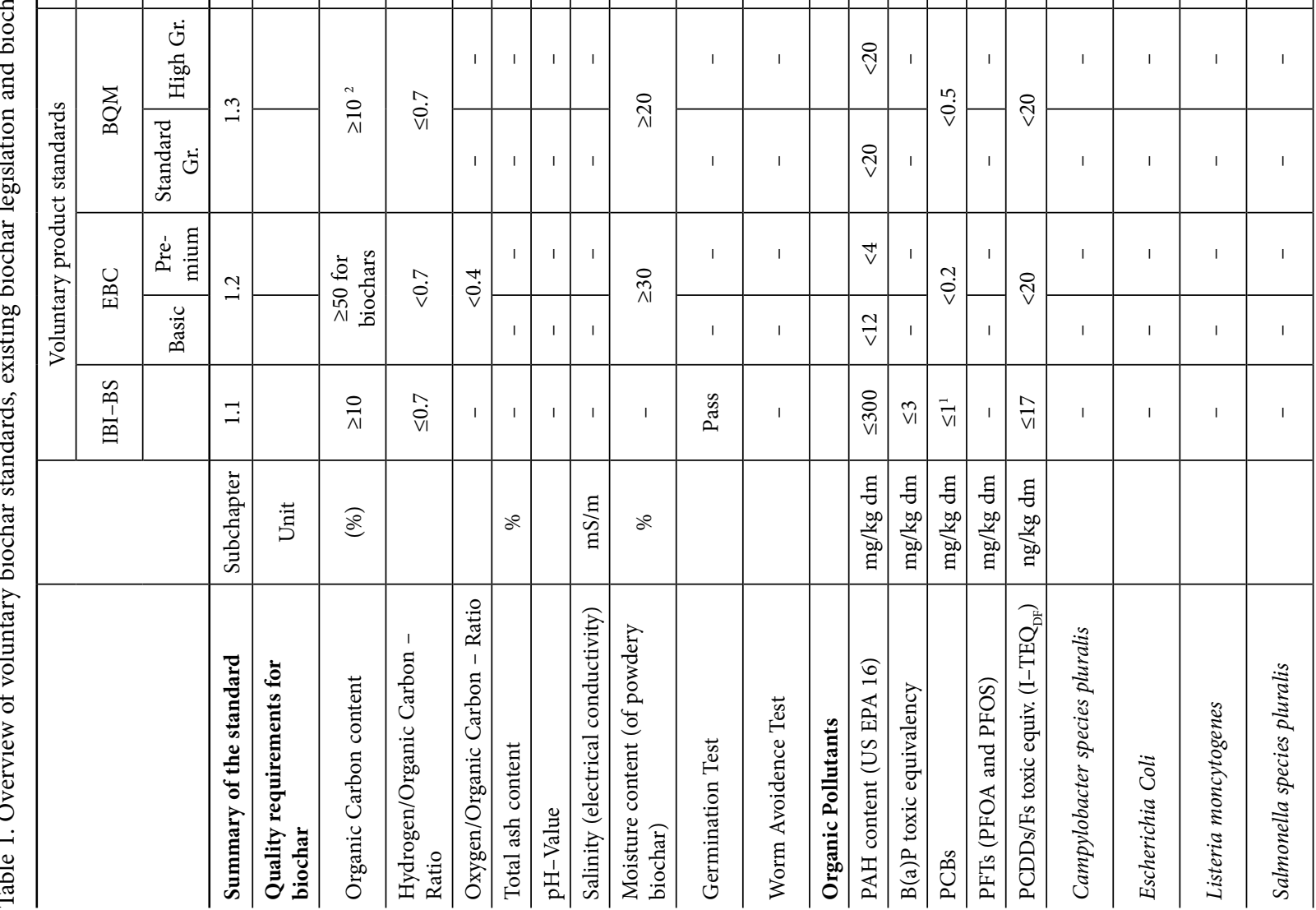




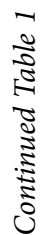

\begin{tabular}{|c|c|c|c|c|c|c|c|c|c|c|c|c|c|c|c|c|c|c|}
\hline 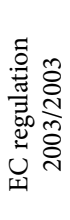 & 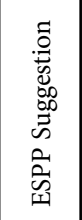 & 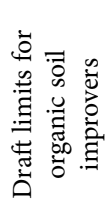 & 1 & $\hat{\mathrm{V}}$ & 1 & $\mathrm{VI}^{2}$ & 1 & 1 & $\begin{array}{c}0 \\
\stackrel{n}{V} \\
\mathrm{~V} I\end{array}$ & $\mid \begin{array}{c}m \\
i \\
\vec{v} \\
\bar{v}\end{array}$ & 1 & 1 & ஓे & 1 & 1 & 1 & 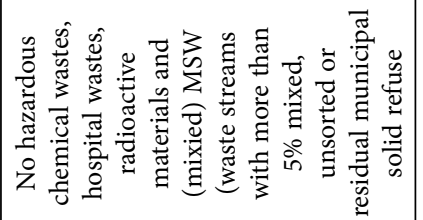 & \\
\hline 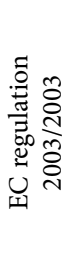 & 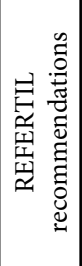 & & $\stackrel{\circ}{\mathrm{V} l}$ & $\stackrel{\stackrel{n}{2}}{\vec{V} \mathrm{~V}}$ & $\begin{array}{l}\stackrel{\Xi}{0} \\
\mathrm{~V} 1\end{array}$ & $\begin{array}{l}10 \\
\tilde{O} \\
\mathrm{~V} \\
\end{array}$ & 1 & $\begin{array}{l}\stackrel{0}{\mathrm{~N}} \\
\mathrm{VI}\end{array}$ & 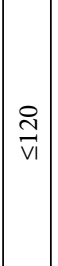 & $\overrightarrow{\mathrm{VI}}$ & & 1 & $\begin{array}{l}8 \\
\stackrel{8}{1} \\
\mathrm{~V} 1\end{array}$ & 1 & 1 & $\begin{array}{l}8 \\
8 \\
0 \\
V 1\end{array}$ & 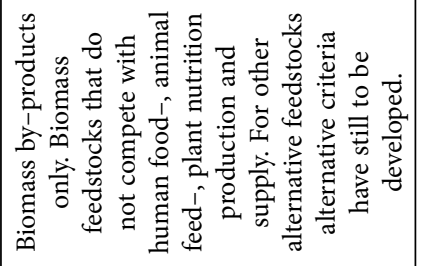 & 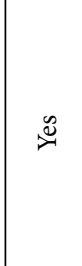 \\
\hline 氙 & 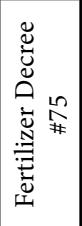 & & 1 & $\stackrel{\stackrel{n}{a}}{\mathrm{~V} \mid}$ & 1 & $\begin{array}{l}n \\
0 \\
0 \\
\mathrm{~V}\end{array}$ & 1 & $\begin{array}{l}\stackrel{D}{\tilde{N}} \\
\mathrm{~V}\end{array}$ & $\begin{array}{l}\text { O } \\
\mathrm{V} \\
\mathrm{V}\end{array}$ & $\frac{n ?}{\vec{V} 1}$ & 1 & 1 & $\begin{array}{l}\stackrel{\Xi}{\mathrm{V}} \\
\mathrm{V} \mathrm{l}\end{array}$ & 1 & 1 & $\begin{array}{l}8 \\
0 \\
0 \\
V\end{array}$ & 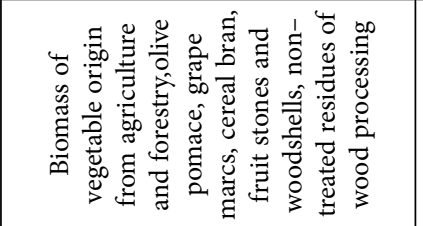 & \\
\hline 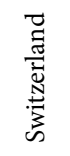 & 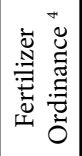 & & 1 & $\overrightarrow{\mathrm{VI}}$ & 1 & 1 & 1 & $\begin{array}{c}\stackrel{8}{0} \\
\overrightarrow{v 1}\end{array}$ & 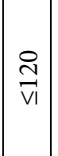 & $\overrightarrow{\mathrm{V}}$ & 1 & 1 & 尺ి & 1 & 1 & 古 & 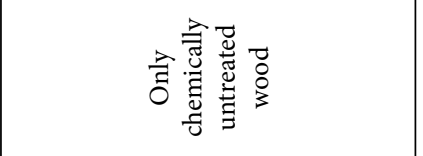 & 1 \\
\hline 陉 & 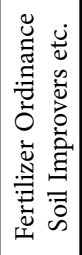 & & 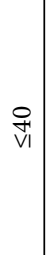 & $\hat{\mathrm{Vi}}$ & 1 & $\mathrm{~V}_{\mathrm{I}}$ & 1 & 1 & $\begin{array}{l}\stackrel{8}{0} \\
\mathrm{~V}_{1}\end{array}$ & $\overrightarrow{\mathrm{V}}$ & 1 & 1 & $\underset{\mathrm{V} 1}{\stackrel{8}{2}}$ & 1 & 1 & 1 & 1 & \\
\hline 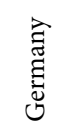 & 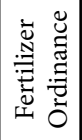 & & 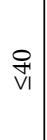 & $\begin{array}{l}\stackrel{20}{\vec{V}} \\
\overrightarrow{\mathrm{V}}\end{array}$ & 1 & $\tilde{V}_{1}$ & 1 & 1 & $\begin{array}{l}\stackrel{0}{1} \\
\vec{v} 1\end{array}$ & $\overrightarrow{\mathrm{V}}$ & 1 & 1 & $\begin{array}{l}\stackrel{8}{\infty} \\
\text { VI }\end{array}$ & 1 & $\overrightarrow{\mathrm{V}}$ & 1 & 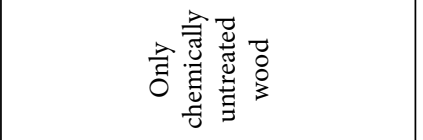 & . \\
\hline$\Sigma$ & 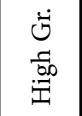 & & $\stackrel{\circ}{\mathrm{V} l}$ & $\hat{\mathrm{V}}$ & $\frac{2}{\vec{V} l}$ & 1 & 1 & O & $\begin{array}{l}8 \\
\dot{0} \\
V_{1}\end{array}$ & $\overrightarrow{\mathrm{V} I}$ & $\begin{array}{l}8 \\
\stackrel{2}{0} \\
\tilde{\omega} \mathrm{v}\end{array}$ & $\stackrel{\circ}{\mathrm{V} I}$ & $\stackrel{\circ}{\mathrm{V} l}$ & $\stackrel{v}{\mathrm{~V}}$ & 1 & $\begin{array}{l}\stackrel{8}{10} \\
\vec{V} 1\end{array}$ & \multirow{2}{*}{ 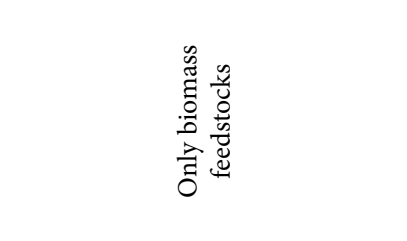 } & \multirow{2}{*}{ 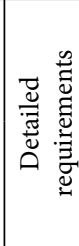 } \\
\hline$\infty$ & 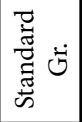 & & $\begin{array}{c}8 \\
\overrightarrow{\mathrm{V}}\end{array}$ & $\stackrel{\tilde{\hat{V}}}{\mathrm{~V}}$ & $\begin{array}{l}8 \\
\mathrm{~V} l\end{array}$ & 1 & 1 & $\begin{array}{c}8 \\
i n \\
\text { VI } \\
\end{array}$ & $\mid \begin{array}{l}8 \\
8 \\
\text { Vi } \\
\end{array}$ & $\hat{\overrightarrow{v l}}$ & 1 & $\stackrel{\stackrel{2}{\hat{V}}}{\mathrm{Vl}}$ & $\begin{array}{l}8 \\
8 \\
0 \\
V 1\end{array}$ & $\frac{8}{\mathrm{~V} l}$ & 1 & $\begin{array}{l}8 \\
\stackrel{0}{0} \\
\mathrm{~N}\end{array}$ & & \\
\hline U & 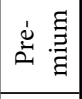 & & $\vec{m}$ & $\vec{v}$ & $\begin{array}{l}D \\
\triangleright \\
v\end{array}$ & 1 & 1 & $\underset{\vec{v}}{\stackrel{8}{ }}$ & 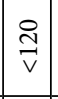 & $\vec{v}$ & 1 & 1 & 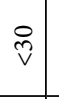 & 1 & 1 & 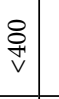 & \multirow{2}{*}{ 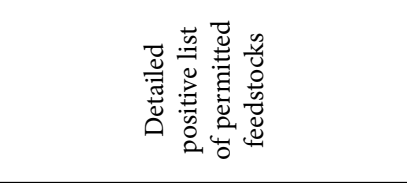 } & \multirow{2}{*}{ 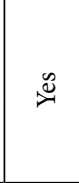 } \\
\hline & 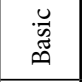 & & $\stackrel{m}{\vec{v}}$ & $\stackrel{n}{\vec{v}}$ & 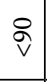 & 1 & । & $\begin{array}{l}8 \\
\vec{v} \\
\end{array}$ & $\begin{array}{l}\stackrel{i}{n} \\
\vec{v}\end{array}$ & $\vec{v}$ & 1 & 1 & $\stackrel{\circ}{\vee}$ & I & 1 & 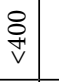 & & \\
\hline $\begin{array}{l}\mathscr{\infty} \\
\stackrel{1}{a}\end{array}$ & & & $\begin{array}{c}8 \\
\stackrel{\mathrm{V} I}{ }\end{array}$ & $\widehat{\hat{v}}$ & 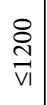 & 1 & $\begin{array}{c}\stackrel{\Xi}{0} \\
\mathrm{v} 1\end{array}$ & $\begin{array}{l}8 \\
\vdots \\
0 \\
\text { vil }\end{array}$ & 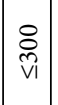 & $\overrightarrow{\mathrm{v}}$ & 1 & $\begin{array}{l}\stackrel{\mathrm{n}}{\hat{\mathrm{V}}} \\
\end{array}$ & 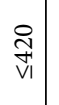 & 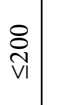 & 1 & 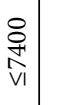 & 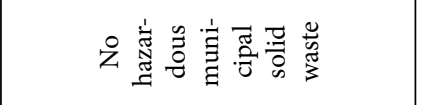 & . \\
\hline & & & 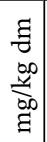 & $\begin{array}{l}\xi \\
\xi \\
00 \\
\frac{q}{00} \\
\Xi\end{array}$ & $\begin{array}{l}\xi \\
\exists \\
00 \\
\frac{q}{00} \\
\Xi\end{array}$ & 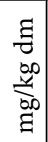 & 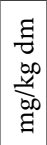 & 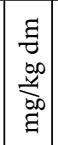 & 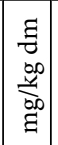 & $\begin{array}{c}\xi \\
g \\
00 \\
\frac{g}{b 0} \\
a\end{array}$ & 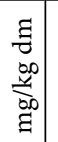 & 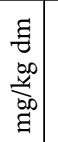 & 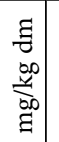 & 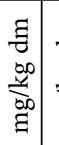 & 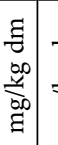 & 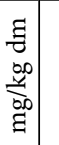 & & \\
\hline
\end{tabular}

$$
\mid
$$

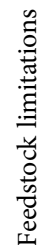




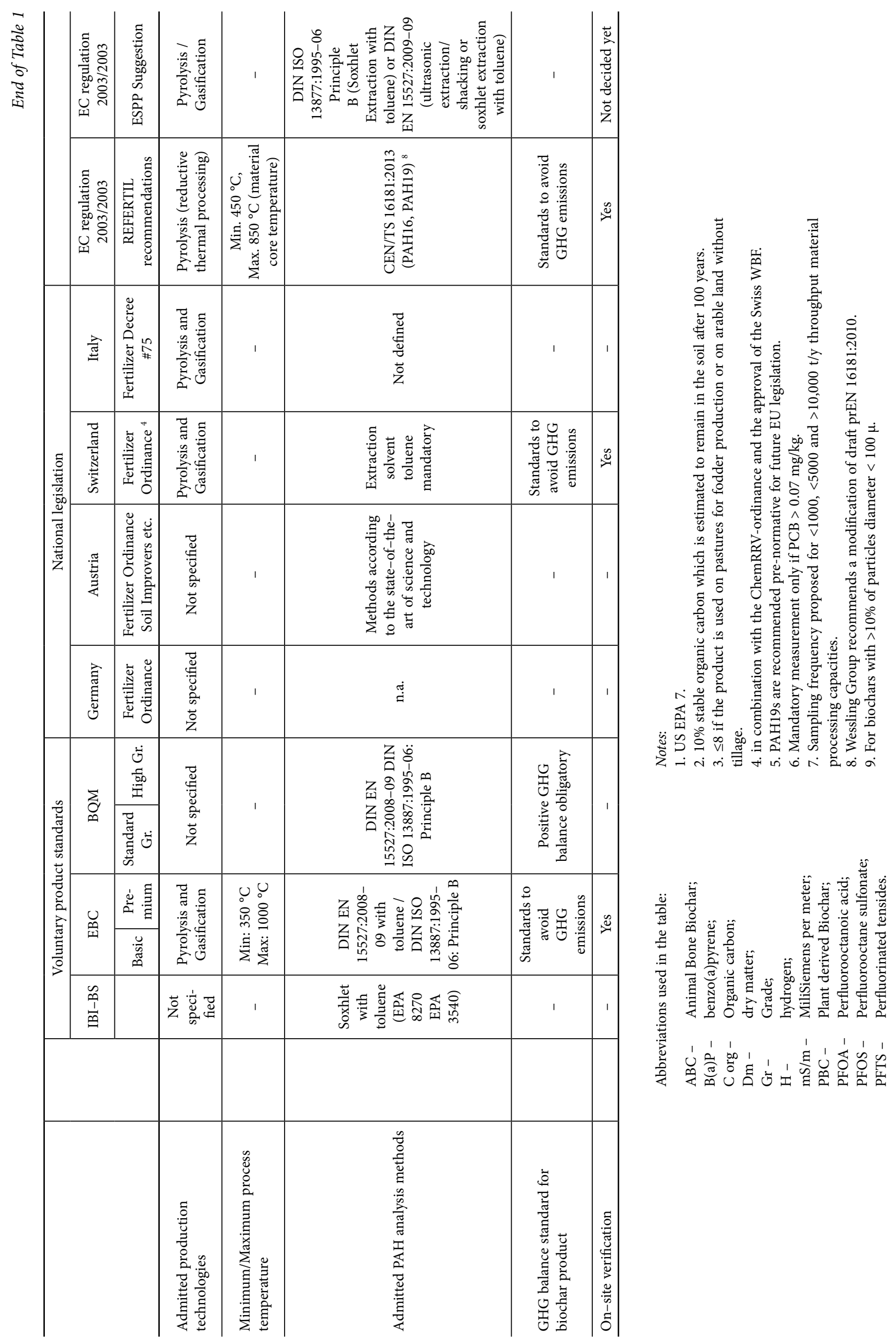


and socioeconomic factors, in a sustainable biochar certification procedure that optimizes complementarity and compatibility between these factors over relevant time periods". In short, the concept suggests carrying out systematic research to use suitable biochar quality grades for different soil application purposes. Arbestain et al. propose a detailed biochar classification system (in Lehmann, Joseph 2015) with the aim to enable stakeholder to identify the most suitable biochar for a particular soil and/or land use and to distinguish the application of biochar for specific niches (a considerable share of the current biochar production is used as cattle fodder supplement). This proposal classifies biochars systematically by their carbon storage value, their fertilizer value and their liming value. It might be useful to consider adopting this classification system for legislative labelling obligations. The next required steps in building a sustainable biochar application system, could be to bridge the gap in the level of scientific understanding of biochars in soils, and to include relevant socio-economic and time scale factors (Verheijen et al. 2012). Any sustainable biochar regulation will benefit from being "adaptive in order to accommodate newly generated knowledge and development. This would perhaps require regular revisions and guideline updates, as well as adjustment of specification thresholds and elimination or re-introduction of test methods, as necessary" as indicated by Verheijen (in Lehmann, Joseph 2015). An ever-present obstacle to speedy advance in important areas on the science-policy interface is the lack of replication to improve the reliability of methods and specific results, because scientists prefer to, or need to, do cutting-edge research. To achieve experimental reproducibility and to begin to populate the global database required to provide sustainable regulation over relevant time scales, industry (i.e. biochar producers) will have to step up its involvement, for example by funding research charities, possibly co-funded by government and other charities (Edwards 2016). We however also need to recognise the limited biochar market share at present and the ability of the market to promote the demand for usefull products. There is a substantial risk of killing this industry. Regulation needs to be proportionate to that risk.

Finally, it might be cost-effective to acknowledge certification according to existing voluntary standards (if those meet the intended degree of ambition) as proof for legislation compliance. The meta-standard approach developed to ensure the sustainability production of biofuels in the EU Biofuel Directive (Directive 2003/30/EC) is a good example for this strategy. Under the meta-standard approach it is obligatory for biochar producers to meet the requirements of the meta-standard, and existing voluntary biochar standards with a sufficient degree of ambition can be used as a proof that the obligation has been meet.

\section{Acknowledgements}

We would like to thank the European Union for the financial support of this publication and the Institute of Biometeorology of the National Research Council of Italy together with the Italian Biochar Association for their content related support of our work. We also wish to acknowledge the Portuguese Foundation for Science and Technology (FCT) for the fellowship of F.G.A. Verheijen (SFRH/BPD/74108/2010).

\section{Funding}

This work was supported by the EU COST Action TD1107 (Biochar as option for sustainable resource management).

\section{Disclosure statement}

Bruno Glaser, Lorenzo Genesio, Sebastian Meyer, Gerhard Soja, Franciscus Verheijen and Ines Vogel declare that he has no competing financial, professional, or personal interests from other parties. Hans-Peter Schmidt declares that he has no competing financial, professional, or personal interests from other parties though he is head of the European Biochar Foundation who issues the EBC certificate. Simon Shackley is Director of the British Biochar Foundation, a community-interest-company in the UK. As such he has a direct interest in the responsible promotion and deployment of biochar in the UK. Edward Someus declares that he has no competing financial, professional, or personal interests from other parties though he is head of TERRA HUMANA Clean Technology Development, Engineering and Manufacturing Ltd, a European animal bone and plant based biochar producer.

\section{References}

Bachmann, H. J.; Bucheli T. D.; Dieguez-Alonso A., et al. 2016. Toward the standardization of biochar analysis: the COST action TD1107 interlaboratory comparison, Journal of Agricultural and Food Chemistry 64(2): 513-527.

https://doi.org/10.1021/acs.jafc.5b05055

DIN ISO 13877:1995-06 - Entwurf. Bodenbeschaffenheit - Bestimmung von polycyclischen aromatischen Kohlenwasserstoffen (PAK) - Hochleistungs-Flüssigkeitschromatographie(HPLC-) Verfahren (ISO/DIS 13877) [online]. Beuth Verlag GmbH. 2016 [cited 10 December 2016]. Available from Internet: https://www.beuth.de/de/norm-entwurf/diniso- $13877 / 2535574$

DIN EN 15527:2008-09. Charakterisierung von Abfällen - Bestimmung von polycyclischen aromatischen Kohlenwasserstoffen (PAK) in Abfall mittels Gaschromatographie-Massenspektrometrie (GC/MS); Deutsche Fassung EN 15527:2008 [online]. Beuth Verlag GmbH. 2016 [cited 10 December 2016]. Available from Internet: https://www.beuth.de/de/norm/dinen-15527/105913650

British Biochar Foundation. 2013. Biochar Quality Mandate (BQM) v. 1.0: Version for public consultation [online], [cited 
12 September 2016]. Edinburgh, United Kingdom. Available from Internet: http://www.geos.ed.ac.uk/homes/sshackle/ BQM.pdf

Bundeskanzleramt Österreich. 1994. Bundesgesetz über den Verkehr mit Düngemitteln, Bodenhilfsstoffen, Kultursubstraten und Pflanzenhilfsmitteln: Düngemittelgesetz 1994 - DMG 1994 [online], [cited 10 December 2016]. Available from Internet: https://www.ris.bka.gv.at/GeltendeFassung.wxe?Abfra ge $=$ Bundesnormen\&Gesetzesnummer $=10010827$

Bundeskanzleramt Österreich. 2004. Verordnung des Bundesministers für Land- und Forstwirtschaft, Umwelt und Wasserwirtschaft, mit der Bestimmungen zur Durchführung des Düngemittelgesetzes 1994 erlassen werden [online], [cited 10 December 2016]. Available from Internet: https://www.ris. bka.gv.at/Dokumente/BgblAuth/BGBLA_2004_II_100/BGBLA_2004_II_100.html

Bundesministerium der Justiz und für Verbraucherschutz. 1999. Bundes-Bodenschutz- und Altlastenverordnung: BBodSchV. [online], [cited 10 December 2016]. Available from Internet: http://www.gesetze-im-internet.de/bbodschv/

Bundesministerium der Justiz und für Verbraucherschutz. 2012a. Verordnung über das Inverkehrbringen von Düngemitteln, Bodenhilfsstoffen, Kultursubstraten und Pflanzenhilfsmitteln: $D \ddot{u} M V$. In: BGBl. I S. 2482. [online], [cited 10 December 2016]. Available from Internet: https://www.gesetze-im-internet.de/bundesrecht/d_mv_2012/gesamt.pdf

Bundesministerium der Justiz und für Verbraucherschutz. 2012b. Verordnung über die Anwendung von Düngemitteln, Bodenhilfsstoffen, Kultursubstraten und Pflanzenhilfsmitteln nach den Grundsätzen der guten fachlichen Praxis beim Düngen: $D \ddot{u} V$. [online], [cited 10 December 2016]. Available from Internet: http://www.gesetze-im-internet.de/bundesrecht/d_v/ gesamt.pdf

Bundesministerium der Justiz und für Verbraucherschutz. 2013. Verordnung über die Verwertung von Bioabfällen auf landwirtschaftlich, forstwirtschaftlich und gärtnerisch genutzten Böden: BioAbfV. [online], [cited 10 December 2016]. Available from Internet: https://www.gesetze-im-internet.de/bioabfv/

Decreto Legislativo 29 aprile 2010, n.75: "Riordino e revisione della disciplina in materia di fertilizzanti, a norma dell'articolo 13 della legge 7 luglio 2009, n. 88", Gazzetta Ufficiale, 2010 [online], [cited 10 December 2016]. Available from Internet: http://www.camera.it/parlam/leggi/deleghe/10075dl.htm

Dehue, B.; Hamelinck, C.; de Lint, S.; Archer, R.; Garcia, E.; van den Heuvel, E. 2007. Sustainability Reporting within the RFTO: Framework Report [online]. Utrecht [cited 10 December 2016]. Available from Internet: http://biomass.ucdavis. edu/files/2013/10/10-18-2013-Ecofys-sustainabilityreporting-May07.pdf

Der Schweizerische Bundesrat. 2005. Verordnung zur Reduktion von Risiken beim Umgang mit bestimmten besonders gefährlichen Stoffen, Zubereitungen und Gegenständen: ChemikalienRisikoreduktions-Verordnung, ChemRRV.

Directive 2003/30/EC of the European Parliament and of the Council of 8 May 2003 on the promotion of the use of biofuels or other renewable fuels for transport, Official Journal of the European Union, 2003 [online], [cited 10 December 2016]. Available from Internet: http://www.bmub.bund.de/ fileadmin/bmu-import/files/pdfs/allgemein/application/pdf/ directive_biofuels.pdf

Directive 2008/98/EC of the European Parliament and of the Council of 19 November 2008 on waste, Official Journal of the European Union, 2008 [online], [cited 10 December 2016]. Available from Internet: https://www.fsai.ie/uploadedFiles/Legislation/Legislation_Update/Dir2008_98.pdf

Directive 2009/28/EC of the European Parliament and of the Council of 23 April 2009 on the promotion of the use of energy from renewable sources, Official Journal of the European Union, 2009 [online], [cited 10 December 2016]. Available from Internet: http://eur-lex.europa.eu/LexUriServ/ LexUriServ.do?uri=OJ:L:2009:140:0016:0062:EN:PDF

Edwards, A. 2016. Reproducibility: team up with industry, $\mathrm{Na}$ ture 531(7594). https://doi.org/10.1038/531299a

European Biochar Foundation. 2012. European Biochar Certificate - Guidelines for a Sustainable Production of Biochar: Version 6.1 of 19th June 2015 [online], [cited 03 February 2016] Arbaz, Switzerland. Available from Internet: http://www. european-biochar.org/biochar/media/doc/ebc-guidelines.pdf

European Commission. 2016. Roadmap: Revision of the Fertilisers Regulation (EC) No 2003/2003 [online], [cited 03 February 2016]. Available from Internet: http://ec.europa.eu/ smart-regulation/roadmaps/docs/2012_grow_001_fertilisers_en.pdf

European Sustainable Phosphorus Platform. 2015. Preparation of input to EU Fertilliser Regulation (revision) criteria for biochars [online], [cited 03 February 2016]. Available from Internet: http://phosphorusplatform.eu/images/ESPP\%20Activities/ESPP\%20biochar\%20fertiliser\%20criteria\%20preparation\%205-10-15.pdf

European Sustainable Phosphorus Platform. 2016. ESPP proposed outline for product criteria for "Biochars and Pyrogenic Carbonaceous Materials" for the (revised) EU Fertiliser Regulation ("EUFR Biochars"): v6/1/2016 [online], [cited 12 February 2016]. Available from Internet: http://phosphorusplatform.eu/images/ESPP\%20proposed\%20EU\%20fertiliser\%20 criteria\%20for\%20biochars\%20v6-1-2016.pdf

Genesio, L.; Vaccari, F. P.; Miglietta, F. 2016. Black carbon aerosols from biochar threats its negative emissions potential, Global Change Biology 22(7): 2313-2314. https://doi.org/10.1111/gcb.13254

Haubold-Rosar, M.; Kern, J.; Reinhold, J. 2016. Chances and risks using biochar and other "processed" biomass as soil improvers or for carbon sequestration. Umweltbundesamt.

Hilber, I.; Blum, F.; Leifeld, J.; Schmidt, H. -P.; Bucheli, T. D. 2012. Quantitative determination of PAHs in biochar: a prerequisite to ensure its quality and safe application, Journal of Agricultural and Food Chemistry 60(12): 3042-3050. https://doi.org/10.1021/jf205278v

International Biochar Initiative. 2014. 2013 State of the biochar industry: a survey of commercial activity in the biochar field: report overview [online], [cited 26 January 2016]. Available from Internet: http://www.biochar-international.org/sites/default/files/StateoftheBiocharIndustry_2013_4pager_final.pdf

International Biochar Initiative. 2015a. Standardized product definition and product testing guidelines for biochar that is used in soil: version number 2.1 [online], [cited 09 December 2016]. Available from Internet: http://www.biochar-international.org/ sites/default/files/IBI_Biochar_Standards_V2.1_Final.pdf

International Biochar Initiative. 2015b. State of the biochar industry 2014 [online], [cited 26 January 2016]. Available from: http:// www.biochar-international.org/State_of_industry_2014

Lehmann, J.; Joseph, S. (Eds.). 2015. Biochar for environmental management: science, technology and implementation. 2nd ed. Routledge. 
Meyer, R.; Rösch, C.; Sauter, A. 2010. Chancen und Herausforderungen neuer Energiepflanzen: Endbericht zum TA-Projekt. Büro für Technikfolgenabschätzung beim Deutschen Bundestag.

Meyer, S.; Glaser, B.; Fischer, D.; Quicker, P.; Noel, Y.; Kuffer, G. 2014. thermal removal of polycyclic aromatic hydrocarbon from gasification biochars, Chapter 12 in M. C. HernandézSoriano (Ed.). Environmental risk assessment of soil contamination. Rijeka, Croatia. https://doi.org/10.5772/57269

Ministero delle politiche agricole alimentari e forestali. Decreto 28 giugno 2016, Gazzetta Ufficiale, 2016 [online], [cited 10 December 2016]. Available from Internet: http://www. gazzettaufficiale.it/atto/serie_generale/caricaDettaglioAtto/ originario?atto.dataPubblicazioneGazzetta=2016-08-12\&atto. codiceRedazionale $=16$ A05930 \&elenco30giorni $=$ false

Regulation (EC) No 2003/2003 of the European Parliament and of the Council of 13 October 2003 relating to fertilisers, Official Journal of the European Union, 2003 [online], [cited 10 December 2016]. Available from Internet: http://eur-lex. europa.eu/LexUriServ/LexUriServ.do?uri=OJ:L:2003:304:00 01:0194:en:PDF

Regulation (EC) No 1907/2006 of the European Parliament and of the Council of 18 December 2006 concerning the Registration, Evaluation, Authorisation and Restriction of Chemicals (REACH), Official Journal of the European Union, 2007 [online], [cited 10 December 2016]. Available from Internet: http://eur-lex.europa.eu/LexUriServ/LexUriServ.do?uri=OJ:L :2007:136:0003:0280:en:PDF

Regulation (EC) No 66/2010 of the European Parliament and of the Council of 25 November 2009 on the EU Ecolabel, Official Journal of the European Union, 2010 [online], [cited 10 December 2016]. Available from Internet: http://eur-lex.europa.eu/LexUriServ/LexUriServ.do?uri=OJ:L:2010:027:0001: 0019:en:PDF

Schimmelpfennig, S.; Glaser, B. 2012. One step forward toward characterization: some important material properties to distinguish biochars, Journal of Environmental Quality 41: 10011013. https://doi.org/10.2134/jeq2011.0146
Schmidt, H.-P.; Shackley, S. (Eds.). 2016. Biochar in European soils and agriculture: science and practice: biochar horizon 2025. London: Routledge.

Schweizerische Eidgenossenschaft. 2013. Provisorische Bewilligung: Gesuch vom 10.12.2010 um Erteilung einer Bewilligung für das Inverkehrbringen von Biokohle als Dünger gemä $\beta$ Artikel 10 ff. der Verordnung vom 10 Januar 2001 über das Inverkehrbringen von Düngern (Dünger-Verordnung, DüV) [online], [cited 26 January 2016]. Bern. Available from Internet: http://www.ithaka-institut.org/ithaka/media/doc/BCSchweiz.pdf

Smith, P. 2016. Soil carbon sequestration and biochar as negative emission technologies, Global Change Biology 22(3): 13151324. https://doi.org/10.1111/gcb.13178

Smith, P.; Davis, S. J.; Creutzig, F. 2015. Biophysical and economic limits to negative $\mathrm{CO} 2$ emissions, Nature Climate Change (in Press). https://doi.org/10.1111/gcb.13178

Terra Humana Ltd. 2014. REFERTIL BIOCHAR EU policy support abstract draft 2014 [online], [cited 4 April 2016]. Available from Internet: http://www.refertil.info/sites/default/ files/REFERTIL_289785_BIOCHAR_POLICY_abstract_ draft_2014.pdf

United Nations Framework Convention on Climate Change. 2015. Adoption of the Paris agreement [online], [cited 26 January 2016]. Available from Internet: http://unfccc.int/resource/docs/2015/cop21/eng/109r01.pdf

van Laer, T.; de Smedt, P.; Ronsse, F.; Ruysschaert, G.; Boeckx, P.; Verstraete, W.; Buysse, J.; Lavrysen, L. J. 2015. Legal constraints and opportunities for biochar: a case analysis of EU law, GCB Bioenergy 7(1): 14-24. https://doi.org/10.1111/gcbb.12114

Verheijen, F. G. A.; Montanarella, L.; Bastos, A. C. 2012. Sustainability, certification, and regulation of biochar, Pesquisa Agropecuária Brasileira 47: 649-653 [online], [cited 12 September 2016]. Available from Internet: http:// www.scielo.br/scielo.php?script=sci_arttext\&pid=S0100204X2012000500003\&nrm=iso

Sebastian MEYER. During his PhD thesis on the ecological benefits and risks of biochar systems, Sebastian has founded the scientific biochar consultancy company WISBER. Sebastian's biochar research activities focus on the thermal removal of polycyclic aromatic hydrocarbons from biochars, on the assessment of the climate mitigation impact of biochar systems, and on legal aspects of biochar production and application. He has also initiated the soil carbon storage project HimmelsErde which offers a voluntary $\mathrm{CO}_{2}$ emission compensation via humus build-up in Germany.

Lorenzo GENESIO. Agronomist, Senior Research Scientist at the Institute of Biometeorology - National Research Council (IBIMET-CNR). His research interests are mainly placed in the domain of land-atmosphere interactions with a specific focus on the impact of land use change on global biogeochemical cycles and agricultural climate mitigation.

Ines VOGEL. Agronomist, research scientist at the Institute of Geographic Sciences at Freie Universität Berlin. Her research activities focus on biochar application in agriculture and horticulture as well as site remediation with special regard to pollutant effects and legal questions.

Hans-Peter SCHMIDT. Directs the Ithaka Institute for Carbon Strategies in Switzerland, since 2007 he set-up hundreds of biochar field trials in Europe and Asia. He developed the Kon-Tiki flame curtain pyrolysis and heads the European Biochar Foundation who issues the EBC certificate.

Gerhard SOJA. Crop Physiologist and Senior Scientist at the Energy Department of AIT Austrian Institute of Technology $\mathrm{GmbH}$. His research studies are focused on global change effects on vegetation and soil, agricultural adaptation and mitigation options with respect to climate change and pollutant effects in the soil-water-plant-air system. 
Edward SOMEUS. Biochar science and technology senior engineer with +30 years specialization and core competence in pyrolysis technology and refined carbon product developments, industrial engineering, NPK nutrient recovery and agricultural applications. Since 2002 coordinator and key technology designer for several large scale EU biochar projects, including high research maturity and high technology readiness level economical scale ups, legal management, product standardization and EU policy support.

Simon SHACKLEY is Programme Director for MSc Carbon Management, University of Edinburgh. His research interests focus upon technological innovation, climate policy and social change. He is also Director of the British Biochar Foundation, a community-interest-company in the UK. As such he has a direct interest in the responsible promotion and deployment of biochar in the UK.

Frank G. A. VERHEIJEN, PhD, research fellow of the Portuguese Science Foundation (FCT), Centre for Environmental and Marine Studies (CESAM), University of Aveiro, Portugal.

Bruno GLASER is professor of Soil Biogeochemistry and pioneer in Terra Preta and Biochar research. He conducted several national and international biochar projects and is chair of the Biochar COST Action. 